Part of Journal of Research of the National Bureau of Standards, Volume 22, May 1939

\title{
EFFICIENCY OF A ROTARY DISTILLATION COLUMN 12
}

\author{
By Beveridge J. Mair and Charles B. Willingham ${ }^{8}$
}

\section{ABSTRACT}

Determinations of the height equivalent to a theoretical plate (H.E.T.P.), hold-up, and through-put were made on a rotary distillation column of the Pegram-Urey-Huffman type having a rectifying section $56 \mathrm{~cm}$ long and $5.08 \mathrm{~cm}$ in diameter. Using as rotating members (1) baskets with fine holes, (2) flat plates, and (3) cones, tests of separating efficiency were made at speeds of rotation ranging from 250 to $1,500 \mathrm{rpm}$ and through-puts ranging from 1 to $10 \mathrm{ml}$ of liquid per minute. The binary system methylcyclohexane- $n$-heptane was used as the test mixture. The lowest H.E T.P. was obtained with the conical rotating members spaced $0.64 \mathrm{~cm}$ apart, with which the following average results were obtained: H.E.T.P., $1.04 \mathrm{~cm}$; hold-up, 1.3 to $1.6 \mathrm{ml}$ of liquid per theoretical plate; maximum through-put, $10 \mathrm{ml}$ of liquid per minute. Within the reproducibility of these experiments, there was no variation in H.E.T.P. for values of throughput from 2 to $10 \mathrm{ml}$ of liquid per minute and speeds of rotation from 250 to 1,500 rpm.

\section{CONTENTS}

I. Introduction $\ldots \ldots \ldots$. 519

II. Column assembly

1. Baskets_..... 522

2. Flat plates $\ldots . . .522$

3. Cones

III. Experiments

IV. Results__._...

V. Conclusion

VI. References_...

\section{INTRODUCTION}

Though many improvements have been made in packed and bubble-cap laboratory distillation columns in the past few years, columns of still greater efficiency are needed for separating hydrocarbons of eight or more carbon atoms per molecule from the gasoline and kerosene fractions of petroleum. Of the major characteristics which describe a distillation column, namely, the height equivalent to a theoretical plate (H.E.T.P.), the hold-up, and the through-put, the through-put is of least importance when the greatest possible separation is desired.

Fenske and coworkers $[1,2,3,4]^{4}$ have made a comprehensive

1 Financial assistance has been received from the research fund of the American Petroleum Institute. This work is part of Project 6, The Separation, Identification, and Determination cf the Constituents of Petroleum.

2 Presented before the Division of Petroleum Chemistry at the ninety-seventh meeting of the American Chemical Society in Baltimore, Md., April 3 to $7,1939$.

8 Research Associates at the National Bureau of Standards, representing the American Petroleum Institute.

- Figures in brackets indicate the literature references at the end of this paper. 
study of the efficiency of packed columns. They found that for a given type of packing in columns from $5.4 \mathrm{~cm}$ to $2 \mathrm{~cm}$ in diameter, decreasing the diameter of the column decreased the H.T.T.P. [1]. The most efficient column described by these authors [3] had an H.E.T.P. of about $2.5 \mathrm{~cm}$, an inside diameter of $2 \mathrm{~cm}$, and was packed with single-turn helices $(0.24 \mathrm{~cm}$ in diameter) made of No. $30 \mathrm{AWG}$ stainless-steel wire. Bruun and coworkers $[5,6,7,8]$ have designed and tested a number of bubble-cap columns. The latest design of this type [7] has an H.E.T.P. of about $2.5 \mathrm{~cm}$ and a hold-up of about $1 \mathrm{ml}$ per theoretical plate. Since so much work has been done on the improvement of packed and of bubble-cap columns, it seems unlikely that a substantial reduction in H.E.T.P. can be made in these columns.

Few data are available on rotary columns of the type designed by Pegram, Urey, and Huffman [9]. Their original column had a diameter of $15.2 \mathrm{~cm}$ and a hold-up of 10 to $20 \mathrm{ml}$ per theoretical plate. Tested by Huffman and Urey [10] with a mixture of ordinary water and deuterium oxide, this column had an H.E.T.P. of about $1.6 \mathrm{~cm}$. However, Huffman and Urey [10] have implied that a considerably better H.E.T.P. might be obtained with a hydrocarbon test mixture.

This paper describes tests with respect to H.E.T.P., hold-up, and through-put made with a hydrocarbon mixture in a rotary column of smaller dimensions than that of Pegram, Urey, and Huffman. These tests were made with different types of plates, different speeds of rotation, and different through-puts.

\section{COLUMN ASSEMBLY}

In all of the experiments, the same column and still assembly were used, but with three types of rotating members: (1) baskets with small holes, (2) flat plates, and (3) cones. The stationary members were in all cases sections of a cone and were held in position with spacers on the inner wall. The complete still assembly with rotating cones is shown schematically in figure 1. This assembly differs from the Pegram-Urey-Huffman column only in minor mechanical details and in the dimensions and spacings of its parts. The fractionating column consists of the cylinder, $G$, and the rotating shaft, $A$, which is located in the axis of the cylinder and which bears the rotating members, $J$ (baskets, plates, or cones). The shaft, $A$, extends through the condenser, $B$, to the motor and is held in position by three bearings. Reflux from the condenser, $B$, flows from the stationary cone to the top of the rotating member, from which it is forced by centrifugal action to the next lower stationary cone. At the lower end of the condenser there is an inner seal, $C$, so that liquid returning from the condenser to the column flows first through the U-tube, $D$, from which samples may be withdrawn as desired. The still pot contains a charging tube into which fits a siphon which extends to a small well in the bottom of the still pot. To the charging tube there is also fitted a manometer, $L$, which contains butyl phthalate. The entire assembly was made of brass, with the exception of the glass sampling tube, $D$, and the manometer tube, $L$. These tubes were attached through standard taper Pyrex-to-brass joints sealed with soft solder.

The length of the cylinder, $G$, was $56 \mathrm{~cm}$, its inside diameter $5.08 \mathrm{~cm}$ and outside diameter $5.4 \mathrm{~cm}$. The diameter of the shaft was $0.95 \mathrm{~cm}$. The spacers which held both the rotating and stationary members had a wall thickness of $0.16 \mathrm{~cm}$. They were made from brass tubing and 
had a sliding fit over the shaft and inside the cylinder. Other dimensions may be obtained from figure 1 .

The column was electrically heated in two sections. Asbestos rope $(0.64 \mathrm{~cm}$ diameter) was hung vertically down the outside of the

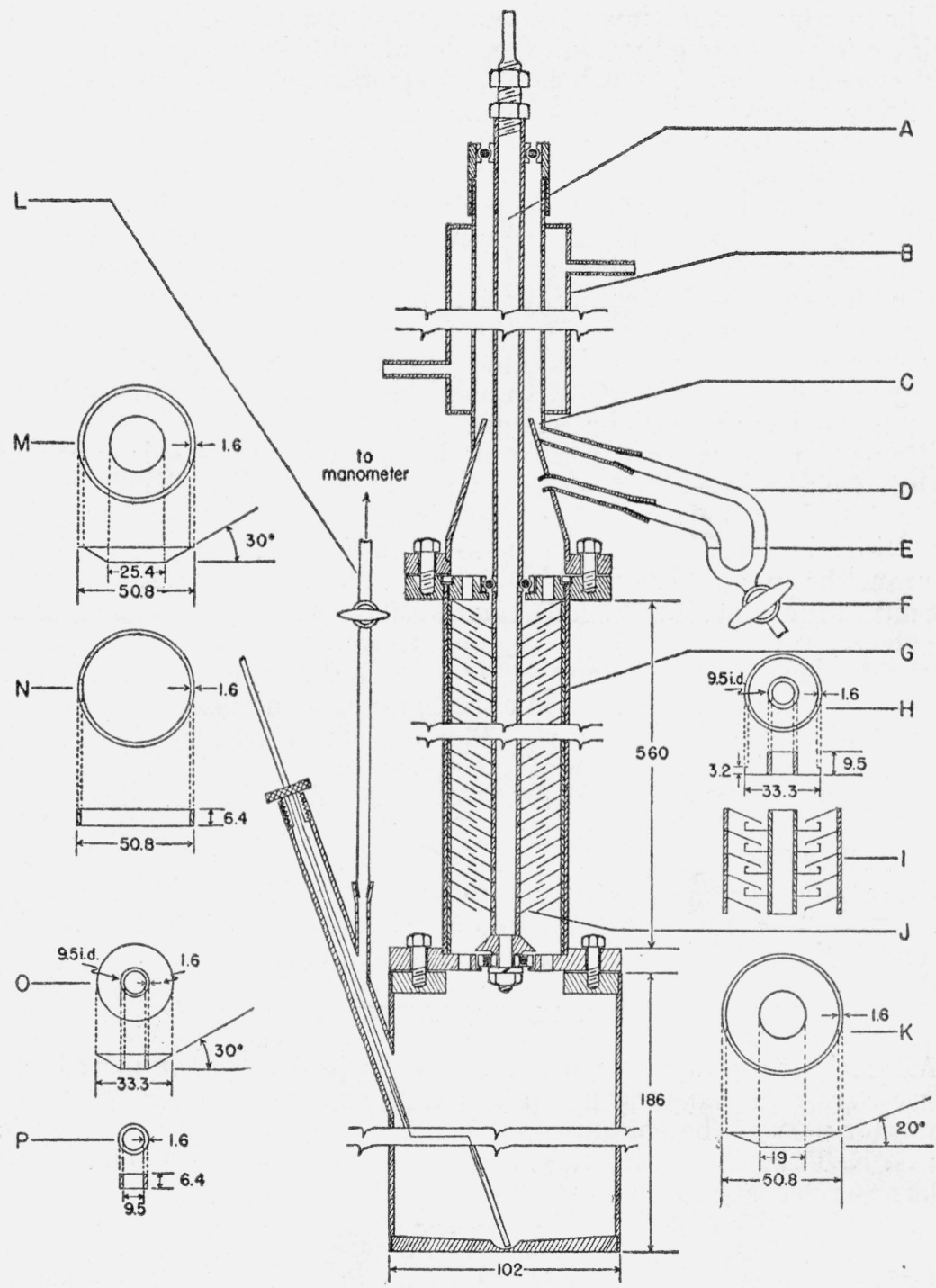

ALL. DIMENSIONS IN MM

Figure 1.-Schematic diagram of distillation column.

column and around this was wound the asbestos-insulated heating wire. The heating wire was covered with a 2.5 -cm layer of magnesiaasbestos. Weston bimetallic laboratory thermometers with dial faces were used to read the temperature of the column. The stems of these 
instruments fitted through the magnesia-asbestos lagging and extended into brass tubes soldered to the outside of the column.

\section{BASKETS ${ }^{8}$}

The greatest separation would appear to be attained in a column in which a fog of colloidally small particles of reflux is traversed by a very slow stream of vapor. Such a column is not practicable, since only an infinitely slow vapor velocity would prevent such a fog from being carried along by the vapor stream. However, in the Pegram-UreyHuffman column there may be an approximation to these conditions. In this column there is between the cylinder walls and the periphery of the rotating cones a gap of $1 \mathrm{~cm}$ in which a spray of fine globules of reflux is traversed by vapor, and it may be that a considerable portion of the efficiency of this column is attributable to the contact between spray and vapor rather than to the contact between the film of liquid on the metal surfaces and the vapor. This idea prompted the experiments with rotating baskets with holes in the outer edge, which it was thought might produce a better spray.

Preliminary experiments were made with baskets of this type and with flat plates in a short section of a 5-cm glass tube. Kerosene was allowed to flow down the tube and air up the tube to simulate the conditions in a column. For visual examination of the inside of the column, the metal spacers which held the stationary cones had strips cut out of the centers. Visual examination gave no information about the size of the globules, but did indicate that the spray produced by the baskets was distributed over a wider area than that from the plates.

A short section of the experimental column with baskets is shown in figure $1(I)$. The baskets were $3.33 \mathrm{~cm}$ in diameter, the sides $0.32 \mathrm{~cm}$ high, and the lip $0.16 \mathrm{~cm}$ wide. In the sides of these baskets were 50 holes (each with a diameter of $0.045 \mathrm{~cm}$ ) arranged in two rows. The stationary cones had an angle of $20^{\circ}$, and the diameter of the hole in the small end of the cone was $1.9 \mathrm{~cm}$. The spacers for both baskets and stationary cones were $0.95 \mathrm{~cm}$ in height. Both the stationary cones and the rotating baskets had a wall thickness of $0.04 \mathrm{~cm}$. The $56-\mathrm{cm}$ section contained 55 baskets and 56 stationary cones.

\section{FLAT PLATES}

After the experiments with the baskets had been completed, the latter were replaced with flat plates of the same diameter $(3.33 \mathrm{~cm})$. No other part of the column was changed, in order that the effect on the H. E. T. P. of substituting flat plates for baskets would be directly determinable.

\section{CONES}

In the experiments with cones, the spacers were reduced to a height of $0.64 \mathrm{~cm}$. This spacing is about the smallest practicable because any closer spacing is likely to cause flooding at very low through-puts. The angle on both sets of cones ( $M$ and $O$, fig. 1 ) was $30^{\circ}$. The diameter of the upper edge of the rotating cones was $3.33 \mathrm{~cm}$, the same as that of the baskets and plates previously used. However, the diameter of the hole at the bottom of the stationary cones was

\footnotetext{
8 Spraying devices similar to these baskets are used in the Maclaurin scrubber [11] to secure intimate con. tact between gases and liquids.
} 
$2.5 \mathrm{~cm}$ compared with $1.9 \mathrm{~cm}$ for the stationary cones used previously. In the direction parallel to their surfaces, the stationary and rotating cones overlapped only about $0.48 \mathrm{~cm}$. It was thought that this small overlap might reduce any tendency to flood caused by the close spacing. The $56-\mathrm{cm}$ section contained 77 rotating cones and 78 stationary cones.

\section{EXPERIMENTS}

The $n$-heptane and methylcyclohexane used in the test mixture were purified by filtration through silica gel and then by distillation in helix-packed columns having a separating efficiency corresponding to about 100 theoretical plates. The data obtained by Bromiley and Quiggle [12] for the analysis of this mixture by refractive index were used. The number of theoretical plates was computed with the aid of the equation derived by Fenske [13], using for the relative volatility, $\alpha$, the value 1.07 given by Beatty and Calingaert [14].

The rotary column is not more difficult to operate than packed or bubble-cap columns and may be left to run unattended. The tests were made under total reflux, small samples of 1 to $2 \mathrm{ml}$ being withdrawn from the still head and still pot at intervals of about 4 hours. When the refractive indices of successive head samples and pot samples were substantiall $v$ constant (usually within \pm 0.0003 ), equilibrium was considered to have been established.

To determine the through-put, the stopcock, $F$, was adjusted so that the liquid level in the $U$-tube fell to $E$ and the rate of flow of condensate just balanced that of the liquid dripping through the stopcock. The volume dripping through the stopcock in unit time was then obtained. It will be noticed from figure 1 that the ring for collecting the condensate was very close to the condenser and considerable condensation probably occurred below this ring. Therefore, the values of through-put recorded are minimum and are not precise to better than $\pm 1 \mathrm{ml}$ per minute.

Hold-up was determined by the method of Tongberg, Quiggle, and Fenske [2]. This method consists in introducing into the dry stil] pot a mixture of known composition of a volatile and a nonvolatile liquid. After the column is operating as desired, a sample is removed from the still pot and the relative concentrations of the volatile and nonvolatile substances are determined. From the change in composition, the hold-up can be computed. Benzene and Marcol (an aromaticfree fraction of petroleum having an initial boiling point of about $230^{\circ} \mathrm{C}$ at $56 \mathrm{~mm} \mathrm{Hg}$ ) were the liquids used. The sample was siphoned from the still pot into a trap chilled with solid carbon dioxide, so that no benzene was lost. The volume of liquid contained in the annular ring and sampling $U$-tube at the head of the still $(4 \mathrm{ml})$ was deducted from the observed values of the hold-up. The hold-up values recorded are, therefore, for the rectifying section and still pot.

\section{RESULTS}

The results of these experiments are tabulated in table 1 in the order in which they were obtained. The lowest H.E.T.P., 0.87 to $1.35 \mathrm{~cm}$, was obtained with the cones which were spaced $0.64 \mathrm{~cm}$ apart (experiments 7 to 27). This is to be compared with an H.E.T.P. of 1.46 to $1.82 \mathrm{~cm}$ for the baskets (experiments 1 to 4 ) and $1.88 \mathrm{~cm}$ 
for the plates (experiments 4 to 6 ) with a $0.95-\mathrm{cm}$ spacing. The plate efficiency, that is, the ratio of the number of theoretical to the number of actual plates, varies from 0.56 to 0.70 for the baskets, is 0.54 for the plates, and varies from 0.54 to 0.84 for the cones. Although the plate efficiency of the baskets does not differ appreciably from that of the cones, it is evident that, since it is not possible to pack together the baskets as closely as the cones, the baskets can not be expected to produce as low an H.E.T.P. Moreover, the baskets are expensive to construct.

TABLE 1.-Results of experiment on rotary column

\begin{tabular}{|c|c|c|c|c|c|c|c|c|c|c|c|}
\hline 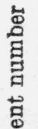 & & $\begin{array}{l}\text { Stationary } \\
\text { members }\end{array}$ & 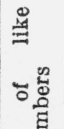 & & $\stackrel{\vec{z}}{*}$ & 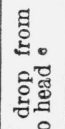 & $\begin{array}{c}\text { Comp } \\
\text { of m } \\
\text { mol } \\
\text { cer } \\
\text { hep }\end{array}$ & $\begin{array}{l}\text { osition } \\
\text { xture } \\
\text { per- } \\
\text { t } n- \\
\text { ane }\end{array}$ & 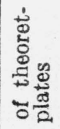 & $\begin{array}{l}\text { Ratio: } \\
\text { Theor. } \\
\text { plates }\end{array}$ & \\
\hline 苋 & & & 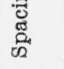 & 迹 & 造 & 焉 & 茫 & 营 & $\begin{array}{l}\text { 罢 } \\
\text { 兄 }\end{array}$ & & 它 \\
\hline $\begin{array}{l}1 \\
2 \\
3 \\
4\end{array}$ & \begin{tabular}{l} 
Baskets. \\
\hdashline do
\end{tabular} & $\begin{array}{l}\text { Cone, angle } 20^{\circ} \\
\text { do } \\
\end{array}$ & $\begin{array}{l}c m \\
0.95 \\
.95 \\
.95 \\
.95\end{array}$ & $\begin{array}{r}r p m \\
500 \\
300 \\
1,500 \\
1,500\end{array}$ & \begin{tabular}{c}
$\mathrm{ml} / \mathrm{min}$ \\
$(\mathrm{liq.})$. \\
7.6 \\
\hdashline 9.6 \\
3.5
\end{tabular} & $\begin{array}{l}\mathrm{mm} \\
\mathrm{Hg} \\
1.38 \\
0.69 \\
-. .\end{array}$ & $\begin{array}{l}20.5 \\
25.9 \\
23.7 \\
23.5\end{array}$ & $\begin{array}{l}69.0 \\
77.4 \\
79.6 \\
81.5\end{array}$ & $\begin{array}{l}30.8 \\
32.6 \\
36.4 \\
38.3\end{array}$ & $\begin{array}{r}0.56 \\
.59 \\
.65 \\
.70\end{array}$ & $\begin{array}{l}\text { cm } \\
1.82 \\
1.72 \\
1.54 \\
1.46\end{array}$ \\
\hline $\begin{array}{l}5 \\
6\end{array}$ & Plates & - & $\begin{array}{l}.95 \\
.95\end{array}$ & $\begin{array}{r}500 \\
1,500\end{array}$ & (10) & $\begin{array}{l}1.00 \\
1.38\end{array}$ & $\begin{array}{l}18.7 \\
14.9\end{array}$ & $\begin{array}{l}64.8 \\
58.5\end{array}$ & $\begin{array}{l}29.7 \\
29.8\end{array}$ & $\begin{array}{l}.54 \\
.54\end{array}$ & $\begin{array}{l}1.88 \\
1.88\end{array}$ \\
\hline $\begin{array}{r}7 \\
8 \\
9 \\
9 \\
10 \\
11 \\
12 \\
13 \\
14 \\
15 \\
16 \\
17 \\
18 \\
19 \\
20 \\
21 \\
22 \\
23 \\
24 \\
25 \\
26 \\
27\end{array}$ & $\begin{array}{l}\begin{array}{l}\text { Cone, angle } 30^{\circ} \\
\text { do }\end{array} \\
\text { do } \\
\text { do } \\
\\
\text { do }\end{array}$ & $\begin{array}{l}\text { Cone, angle } 30^{\circ} \\
\\
\\
\\
\end{array}$ & $\begin{array}{l}.64 \\
.64 \\
.64 \\
.64 \\
.64 \\
.64 \\
.64 \\
.64 \\
.64 \\
.64 \\
.64 \\
.64 \\
.64 \\
.64 \\
.64 \\
.64 \\
.64 \\
.64 \\
.64 \\
.64 \\
.64\end{array}$ & $\begin{array}{r}500 \\
1,500 \\
1,500 \\
1,500 \\
1,500 \\
1,500 \\
1,500 \\
1,500 \\
500 \\
500 \\
500 \\
500 \\
500 \\
500 \\
1,500 \\
1,500 \\
1,500 \\
250 \\
250 \\
250 \\
250\end{array}$ & $\begin{array}{l}0.8 \\
(2) \\
6.7 \\
2.8 \\
5.2 \\
8.5 \\
4.8 \\
4.8 \\
4.7 \\
7 \\
1.8 \\
3.4 \\
3.7 \\
1.0 \\
5.6\end{array}$ & $\begin{array}{l}1.53 \\
1.30 \\
1.15 \\
1.69 \\
1.30 \\
0.77 \\
1.00 \\
1.07 \\
1.46 \\
1.07 \\
1.23 \\
1.61 \\
1.15 \\
1.15 \\
1.30 \\
1.53 \\
1.15 \\
0.84 \\
.84 \\
.61 \\
.92\end{array}$ & $\begin{array}{r}24.3 \\
19.0 \\
27.0 \\
16.6 \\
10.8 \\
20.5 \\
14.1 \\
6.8 \\
21.8 \\
22.4 \\
27.0 \\
25.3 \\
21.9 \\
16.4 \\
14.8 \\
12.6 \\
21.1 \\
19.2 \\
20.8 \\
17.4 \\
17.1\end{array}$ & $\begin{array}{l}85.1 \\
87.7 \\
94.6 \\
86.0 \\
80.2 \\
85.1 \\
83.8 \\
66.0 \\
92.4 \\
90.8 \\
95.8 \\
91.2 \\
94.6 \\
92.4 \\
90.8 \\
85.4 \\
95.8 \\
93.4 \\
88.0 \\
88.9 \\
83.1\end{array}$ & $\begin{array}{l}41.5 \\
49.8 \\
55.8 \\
49.5 \\
50.7 \\
44.8 \\
50.0 \\
47.5 \\
54.7 \\
51.2 \\
59.7 \\
49.6 \\
60.2 \\
60.0 \\
58.7 \\
53.7 \\
64.7 \\
59.3 \\
48.1 \\
52.7 \\
45.4\end{array}$ & $\begin{array}{l}.54 \\
.65 \\
.72 \\
.64 \\
.66 \\
.58 \\
.65 \\
.62 \\
.71 \\
.67 \\
.78 \\
.64 \\
.78 \\
.78 \\
.76 \\
.70 \\
.84 \\
.77 \\
.62 \\
.68 \\
.59\end{array}$ & $\begin{array}{l}1.35 \\
1.12 \\
1.00 \\
1.13 \\
1.10 \\
1.25 \\
1.12 \\
1.18 \\
1.02 \\
1.09 \\
0.94 \\
1.13 \\
0.93 \\
.99 \\
1.04 \\
0.87 \\
1.94 \\
1.06 \\
1.23\end{array}$ \\
\hline
\end{tabular}

s There were 55 rotating and 56 stationary members for experiments 1 to 6 and 77 rotating and 78 stationary members for experiments 7 to 27 .

$b$ For the basket-shaped rotating members, $0.95 \mathrm{~cm}$ apart, the flooding through-put is 25 to $30 \mathrm{ml}$ of liquid per minute; for the flat-plate rotating members about the same; and for the conical rotating members, about 10 to $12 \mathrm{ml}$ of liquid per minute. The values in brackets in this column were estimated from the pressure drop.

- The values recorded in this column were obtained by conversion of the readings of butyl phthalate

It is evident from figure 2 that the speed of rotation has no significant influence on the H.E.T.P. Huffman and Urey [10] found this true for their larger column with mixtures of ordinary water and deuterium oxide.

Within the reproducibility of these measurements, there appears also to be little if any variation in H.E.T.P. with through-puts varying from 1 to $10 \mathrm{ml}$ per minute. With experiment 12 (not plotted in fig. 2) a lower efficiency was obtained. The through-put for this experiment was not determined, but, judging from the pressure drop, it 

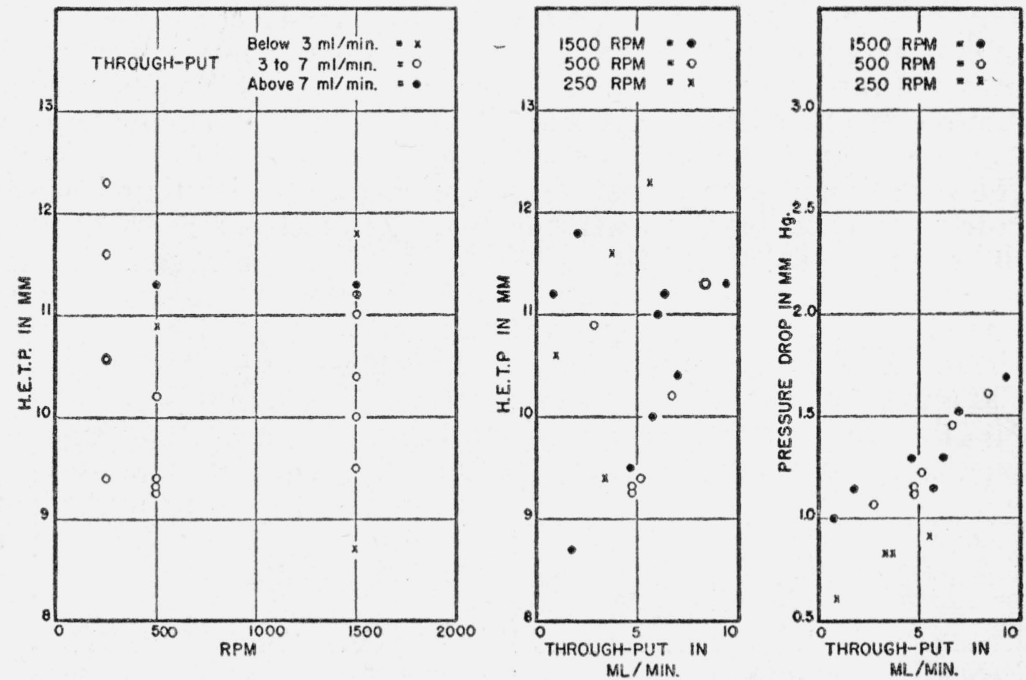

Figure 2.-Chart showing for the column with conical rotating members: (a) H.E.T.P. with respect to revolutions per minute; (b) H.E.T.P. with respect to through-put; and (c) pressure drop with respect to through-put.

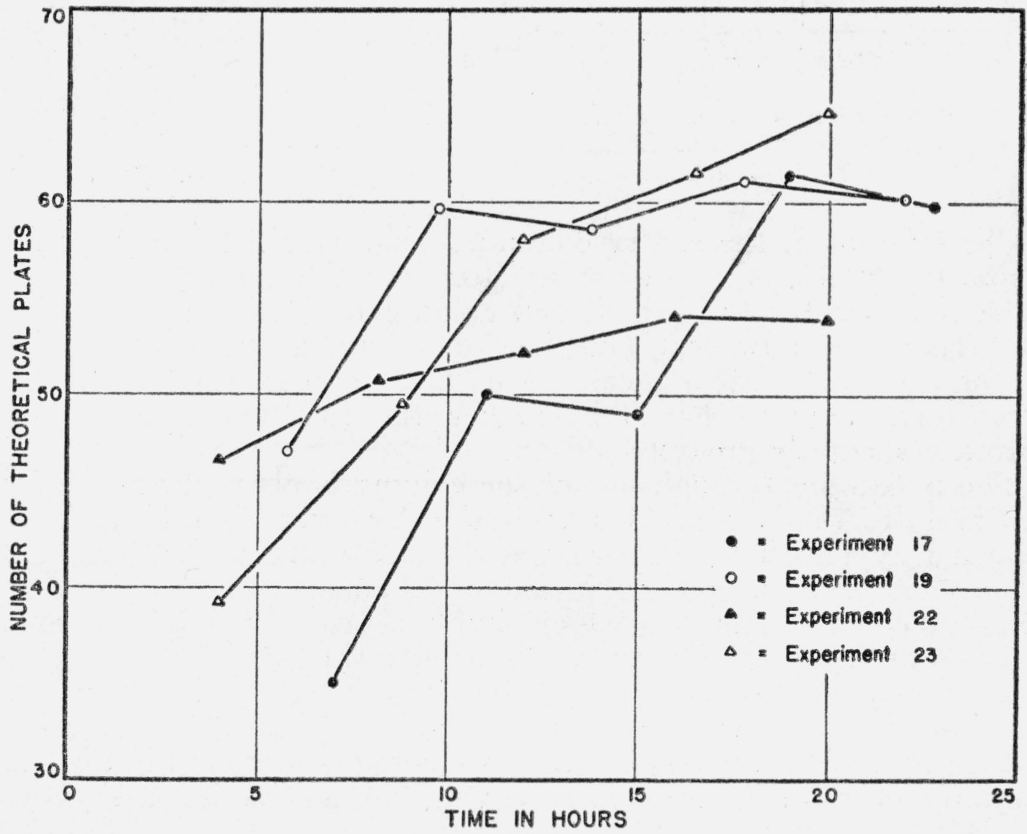

FIGURE 3.-Chart showing variation in number of theoretical plates with respect to time. 
must have been very small, and it is questionable whether sufficient liquid was present to wet adequately the metal surfaces.

As is to be expected, the pressure drop in the column is greater, the greater the through-put. The pressure drop depends to some extent on the speed of rotation. At least it is less for a given through-put at $250 \mathrm{rpm}$ than at 500 or $1,500 \mathrm{rpm}$.

The variation in the number of theoretical plates with time is shown for a few typical experiments in figure 3. After about 10 to 12 hours equilibrium is substantially established. Although sometimes a decrease and sometimes an increase in theoretical plates occurs after 12 hours, this variation is apparently normal for the column.

The variation in hold-up for various through-puts at rotation speeds of 500 and $1,500 \mathrm{rpm}$ is shown in figure 4. The hold-up varies from about 70 to $86 \mathrm{ml}$ with through-puts varying from 2 to $10 \mathrm{ml}$ and does not depend appreciably on the speed of rotation, although at lower

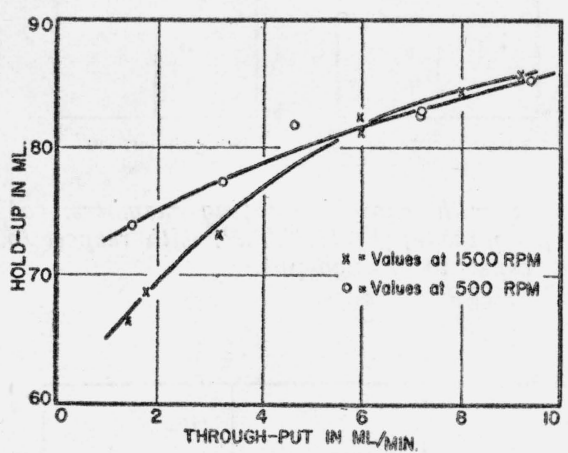

FIGURe 4.-Chart showing the relationship between hold-up and through-put for two speeds of rolation. through-puts there appears to be a slightly lower hold-up at higher speeds.

\section{CONCLUSION}

Disregarding experiment 7, since it was the first of a series, and experiment 12 , for reasons already mentioned, the average value of the number of theoretical plates, using closely spaced cones, is 54, which corresponds to an H.E.T.P. of $1.04 \mathrm{~cm}$. This may be compared with an H.E.T.P. of $2.5 \mathrm{~cm}$ for the best bubble-cap [7] or packed columns [3].

The hold-up of the rotary column though small, 1.3 to $1.6 \mathrm{ml}$ per theoretical plate, is somewhat greater than the $1 \mathrm{ml}$ per theoretical plate reported for the bubble-cap column by Bruun and Faulconer [7]. Tongberg, Lawroski, and Fenske [3] have not reported the holdup for their helix-packed column of 2-cm diameter. However, the great advantage in H.E.T.P. makes the rotary column valuable despite its slightly greater hold-up.

The maximum through-put of the column is about $10 \mathrm{ml}$ of liquid per minute. This compares with slightly over $20 \mathrm{ml}$ per minute reported by Tongberg, Lawroski, and Fenske [3] for the 2-cm packed column and to $30 \mathrm{ml}$ per minute of liquid benzene reported by Bruun and Faulconer [7] for the 2.5-cm bubble-cap column. This smaller through-put is of secondary importance in thelast stages of the isolation of hydrocarbons from petroleum, where the time saved by effective distillation greatly outweighs the time involved in the distillation itself.

Judging from these tests, it appears possible to install in a room of ordinary height a laboratory rectifying column having a separating efficiency of from 200 to 250 theoretical plates.

The authors express their gratitude for the advice and encouragement of F. D. Rossini. 


\section{REFERENCES}

[1] M. R. Fenske, C. O. Tongberg, and D. Quiggle, Ind. Eng. Chem. 26, 1169 (1934).

[2] C. O. Tongberg, D. Quiggle, and M. R. Fenske, Ind. Eng. Chem. 26, 1213 (1934).

[3] C. O. Tongberg, S. Lawroski, and M. R. Fenske, Ind. Eng. Chem. 29, 957 (1937).

[4] M. R. Fenske, S. Lawroski, and C. O. Tongberg, Ind. Eng. Chem. 30, 297 (1938).

[5] J. H. Bruun, Ind. Eng. Chem., Anal. Ed. 1, 212 (1929).

[6] J. H. Bruun, Ind. Eng. Chem., Anal. Ed. 8, 224 (1936).

[7] J. H. Bruun and W. B. M. Faulconer, Ind. Eng. Chem., Anal. Ed. 9, 192 (1937).

[8] J. H. Bruun and S. D. West, Ind. Eng. Chem., Anal. Ed. 9, 247 (1937).

[9] G. B. Pegram, H. C. Urey, and J. R. Huffman, Phys. Rev. 49, 883 (1936); J. Chem. Phys. 4, 623 (1936).

[10] J. R. Huffman and H. C. Urey, Ind. Eng. Chem. 29, 531 (1937).

[11] Walker, Lewis, and McAdams, Principles of Chemical Engineering, 2d ed., p. 474 (McGraw Hill Book Co., New York, N. Y., 1927).

[12] E. Bromiley and D. Quiggle, Ind. Eng. Chem. 25, 1136 (1933).

[13] M. R. Fenske, Ind. Eng. Chem. 24, 482 (1932).

[14] H. A. Beatty and G. Calingaert, Ind. Eng. Chem, 26, 504 (1934).

Washington, February 10, 1939. 